\title{
Ow(l)etter party - Tulum s(l)ova - Project of Promoting the Enjoyment in Reading
}

\author{
Draženka Stancic, School Librarian \\ Elementary School of Ivan Kukuljević Sakcinski, Ladislava Sabana 17, 42240 Ivanec, \\ Croatia \\ Telephone/Fax: +38542781330 \\ Cell: +385996747348 \\ E-mail: drazenka.stancic@gmail.com
}

\begin{abstract}
The basic goal of the Ow(1)etter party project is strenghtening of the positive attitude of the pupils toward the enjoyment reading. It was concieved as the annual cycle which begins with the Night reading session in the school library on the last week in October of the school year. The session includes various activities, but the obligatory activity is the ceremonial enjoyment reading, and the recommended socializing with other school libraries through the Skype, and sleeping in the sleeping bags, since not all libraries have the adequate conditions. In the next 11 months, the pupils conduct the Reading in the local community (in institutions, associations, companies and in public spaces). The actions are documented, and in the last month of the project, the decision is made about the most successful school library. The project presently includes 22 school libraries.
\end{abstract}

\section{The origins of the Ow(l)etter party project}

\section{The enjoyment reading and school library}

The school librarians in Republic of Croatia, in accordance with the mission and the tasks of school libraries, are actively involved in designing the activities for their users with the purpose of encouragement of all types of reading (IFLA/UNESCO School Library Manifesto, 2004; HKD, p. 32). Reading with understanding (informative reading) is the skill which is a precondition for success in education, in work and in life, especially in our age, when we are each day burdened with loads of information and when we need, more than ever before, the skill of recognition and use of important information. It is a generally known fact that, because of the inadequately developed reading skills, the pupils resist the reading, which they see as an obligation. We propose that the enjoyment reading leads inevitabely to the development of the information reading, i.e. reading with understanding. Enjoyment reading is in our minds related most often with the evenings when some of our loved ones shared with us the joy of reading. This is a neglected activity, because of numerous obligations of the family members and the school programs based upon the reading with understanding. The enjoyment reading develops the reading skills, and it ceases to be an effort.

Our intention is to popularize the skill of reading through the enjoyment reading, so the final result would be the developed skill of reading with understanding. 


\section{The creation of the Ow(l)etter party project}

The Ow(l)etter party project is a project which was designed with this particular goal in mind. It was created on request of the colleagues librarians who were introduced to the night reading session in ES Ivan Kukuljević Sakcinski, which took place on the Day of School Libraries, on October 30th 2009. In the present form, it is the joint project of ES Ivan Kukuljević Sakcinski, Ivanec, Croatian Association of School Librarians, CASL, and Croatian Network of School Librarians, CNSL, which presently includes 22 school libraries from whole Croatia. The project is presently in 3rd phase of implementation, and will be completed 15 days before the start of the IASL 2012 Conference The Shifting Sands of School Librarianship.

For the large scale implementation, Ow(l)etter party has a project implementation team from the Ivanec elementary school led by the school librarian Draženka Stančić, the author of the project. Beside the author, the team consists of the school counsellor Vesna Vitez, social pedagogue Iva Kelemen, German language teacher Jasenka Habek and art teacher Martina Gregur. Because of that, all the school librarians included into the project have been provided with the detailled Project activity time schedule, which left enough place for the sensibilities of the pupils and the project implementation team in each school library. They were also provided with the Instructions for adoption of the rules of behavior for the reader's meeting, the Flyer for the parents with the returnable Parents' statement by which the parents provide the emergency case information and allow the children to be in the school library and to be documented on photos and videos, the Example of associations for the Associations game, the flyer Evaluation of activities of the night reading mission, Announcement for the local media, and finally, Parents' compliance for the participation in the next project phase. Through the Instructions for adoption of the rules of behavior and the Flyer for the parents with the Parents' statement we have ensured that there will be no obstructions and no incidents on the night reading sessions, and this flyer, along with the Parents' compliance for the second phase, fulfills all possible legal requirements. The school libraries have been also provided with the project logo (the author was Tihomir Dunđerović, our colleague from the CNSL association), the posters and the bookmarkers (the author was Božidar Breški, instructor - counsellor in extracurricular activity of photo activities).

\section{The goals and the description of the project}

The goals of the project

- to promote the positive attitude of the pupils of higher and lower elementary school grades toward the reading, through promotion of the enjoyment reading and through emphasizing the importance of the enjoyment reading in the local community, which will enable the students to achieve self-realization and sense of importance.

- beside the reading skill, to improve the following competences of the students: communication in native language, digital competence, learning how to learn, social and citizen competence, initiative and activity, cultural awareness and expression (National framework curriculum for the preschool upbringing and the general obligatory and high school education, 2011; MZOŠ, p. 17) 
- to offer new cultural services to the local community in the form of enjoyment reading aloud, and to strenghten the positive attitude of the local community toward reading.

- to promote the profession of school librarian through the publishing of the project activity

The Ow(l)etter party project envelops several general curriculum topics: Personal and social development, Learning how to learn, Use of information and communication technology, Citizen upbringing and education (National framework curriculum for the preschool upbringing and the general obligatory and high school education, 2011; MZOŠ, p. 42), which confirms its justification in the upbringing and education.

\section{Project description}

The project is based upon the implementation of several attractive activities for the pupils-users of the school libraties, beside the key activity - enjoyment reading aloud, which should be introduced to the pupils in such way that they become its promotors. There are two key points in the project: reading aloud within the frame of the night reading sessions, and reading to the adults and the children in the local community.

The reading aloud within the frame of the night reading session will be implemented through something we have called ceremonial reading, because of our intention to emphasize this activity among other attractive activities. The ceremonial reading is conducted in following manner: lit candles are placed on the tables and the floor of the library, and there is absolute silence while the participant of the session reads aloud his/her chosen text lighted by the torchlight. The rest of the participants focus their torchlights on the book of the participant who is reading, and all are comfortabely laying on the mattrasses (or sleeping bags, if they stay overnight in the library).

The initial reading is conducted by the school librarian, leader of the team, who also announces the event before he/she starts with the reading. Before the reading, every participant has to present himself/herself and the reason why he/she has choosen the selected text. After the reading, and before the next reader, the school librarian makes positive comment of the reader's effort (he/she has to find at least one positive commentary thing in the reading of the pupil) and invites the other readers to make a positive comment, which they do if they are willing. In such way, a special atmosphere of togetherness is created.

The pupils then conduct the reading in the local community, knowing that the reading aloud to the others is a positive, unusual, but good activity. Reading to the adults and the other children places them into the position to strenghten their self-confidence, because they read to someone who is older, or to other children, who would like to be in their place, who look up to them; in this way, they gain a sense of importance. The child who participated in this project will have a positive attitude toward the reading and will defend this attitude among the peers, and will also pass this attitude to his/her children in the future. Through enjoyment reading in the local community, the pupils develop inter-generational communication and the positive attitude toward the persons with special needs, if they read aloud to such persons. 
The texts which are used on the night reading session are the free choice of the pupils; however, they should be well timed, not longer than ten minutes of reading per pupil. The texts which are used for reading in the local community are partially freely choosen, but are also considered on the meeting of the pupils and the implementation team, taking into account the criteria of the age of auditory, and their supposed interest.

Within the scope of the project, the pupils also use the tools of the information technology and the information Internet services because of the communication with the pupils from other school libraries which implement the project and because of promotion of the enjoyment reading through the publishing the session reading materials (under the supervision of the implementation team). These texts are the part of the documentation and the promotion of the project, and on this basis, it will be decided which library was the most successful in promotion of the enjoyment reading.

The project consists of the obligatory and variable parts, which depend upon the preferences of the pupils and implementation teams in particular libraries. The obligatory parts are the ceremonial enjoyment reading, use of web 2.0 service, and reading in the local community, and the variable parts are the duration of the night reading session (with or without sleeping in the library), the program of activities in this session beside the ceremonial reading, the connection of the libraries through Skype, and the selection of the institution, association, company or public room for the enjoyment reading.

\section{Phases and results of the project}

Ow(1)etter party consists of four phases. The first and the final are technical in character: preparation and evaluation phase. On the other hand, the second and the third are content phases.

\section{Preparation phase}

In the first phase, the team for project implementation was established, which then proceeded to design the project. Support of the school librarian association was also aqcuired (Croatian Network of School Librarians and Croatian Association of School Librarians). The project was promoted among the peers on the 23rd Spring School Librarians in Osijek, with the help of heads of ŽSV in Republic of Croatia. The following phase was the agreement with the interested school libraries - there were 26 in the start. The media at the state level were informed, and each library was sent the Announcement for the local media, so that they can inform the local media. Also, the school libraries were sent all the above mentioned documents required for the preparation of the second phase of the project. The group Tulum s(l)ova (Ow(l)etter party) was opened on the Facebook (http://www.facebook.com/groups/tulumslova/). The counselling support of the Croatian Network of School Librariant to the school teams was ensured, with the goal of opening Internet profiles of the school libraries. The persons responsible for the preparation phase were the project implementation team, Ivana Vladilo, chairman of the Croatian Network of School Librarians, Vanja Jurilj, chairman of the Croatian Association of School Librarians, and the interested school librarians. 


\section{Night reading session}

The second phase was initiated on October 28th 2011 for the most of the libraries, and consisted of the following steps: preparation of the session at the level of each school library, implemetation of the session, and the evaluation. A reserve date was also given: November 4th 2011. After that, three more schools had the night sessions, on November 9th, 16th and 25th. The last one has repeated the night session on December 16th. The school librarians have informed the colleagues and headmasters, organized the school teams, informed the pupils, designed the activities with the pupils, informed the parents, acquired their agreement, and informed the media. Facebook, YouTube and Skype profiles of the libraries were opened. Documentation of the sessions through photo and video recordings was agreed upon. The sessions were conducted within the time schedule on the two planned dates, and two more dates required by the project leader. In accordance with the present conditions, the sessions with other libraries through the Skype service were included, as well as spending the night in the library rooms. Beside the ceremonial readings and socializing over the Skype, the teams had the option to conduct the activities like board games, movie watching, art and literary workshops, workshops for life (social) skills, karaoke, drama improvisations, literary meeting etc. After the sessions, the evaluation papers were gathered, and/or oral evaluations of the session participants were acquired (both from the pupils and the team members). The pupils were given the Parents' compliance papers for the next phase of the project. The session documentation was loaded on the Internet services, and the reports were sent to the author of the project. The responsible persons were the school teams, with the support of the pupils. After the report about the implemented activities within the project on 24th Spring school of school librarians in Dubrovnik, twho high schools and one elementary school have joined the project (Technical school, Cakovec had the night reading session of April 27th 2012, Industrial and crafts school, Sisak, was included in the project in the third phase, together with the Elementary school 'Braća Bobetko', Sisak, on March 15th 2012; they conducted the reading session in the Mountain resort on Hrastovička gora with 10 pupils and one guest - a pupil from the Crafts school Sisak. ES Petra Perice from Makarska was included in the project in the third phase; they conducted reading session in the Town library Makarska on the Night of the Book.)

\section{Reading in the local community}

The third phase was initiated after the night reading session on October 29th 2011. The Parental compliances for this phase of the project were gathered. The pupils were treated as the part of the team. Together with the librarian and the teachers, they planned visits to the institutions, associations and companies of the local community, depending upon the ideas of the extended school team; after that, they read the texts to the users of these institutions, associations and companies, which was documented by recording and loading on the Internet profiles of the libraries. The number of the reading team members is not defined, except that there should be an adult person and at least three pupils. The texts which they read in this phase are adjusted to the communication of the pupil readers with the expected auditory; these could be short storied, novels or fragments of novels and fiction books, poetry, newspaper articles, commentaries/blogs. The reading session lasts from 20 to 30 minutes, unless asked differently by the auditory, and the pupil readers and the teachers agree. The auditory also has the option 
to initiate a short discussion, with the previous agreement with the persons responsible for the reading rooms. It is also agreed whether the reading will be done in the ceremonial atmosphere, or the factor of surprise and unusual events is enough. The extended team informs the press and the electronic media and invites them to follow the event; the team also gathers media announcements and links the electronic media articles with the Facebook site of the library and the Facebook site of the Ow(l)etter party. It also publishes the scanned pictures from the press media. The persons responsible for the activity are the extended school teams.

\section{Evaluation of the $O w(l)$ etter party project}

Fourth phase will start on October 1st 2012, and lasts until the end of the project, October 29th 2012. The extended school teams will fill the questionnaire. Threemember committee (a member of CNSL, a member of CASL and a public person from the culture field - persons who have not been included in the project implementation) will review the sites of the Ow(l)etter party and the Internet profiles of the libraries and will decide which library was the most successful. The media presence for all teams will be ensured, especially for the most successful library, and the simbolic fee for all the libraries included by the Croatian Association of School Librarians. A report about the achieved results will be written and submitted to the AC CASL and AC CNSL, whish will give their opinion. The report will be published on the Facebook site of the Ow(l)etter party, the school sites of the libraries included in the project (all teams), on UDK 02, and the CASL and CNSL web sites. If the project is evaluated as good enough, it will be further promoted at the state and international level. The persons responsible for the activity are the team for project implementation, committee for the selection of the most successful library, AC CASL and AC CNSL.

\section{Project results at the moment}

The preparation phase and the phase of night reading session in the school libraries are over. The phase of visiting the local community is presently active, and the phase of evaluation will take place in October 2012. In the first phase, our goal was to include at least 6 libraries. There were 26 interested and 19 included school libraries at the beginning of the project; in our opinion, this was rather successful. All materials were submitted on time, the parents were informed about the project, and the teams, schools and pupils were prepared. 
Table 1. Number of participant on the Night reading session of the Ow(l) party project

\begin{tabular}{|c|c|c|c|c|}
\hline Schoo library & $\begin{array}{c}\text { School } \\
\text { team }\end{array}$ & Pupils & Guests & Total \\
\hline ES Ivana Kukuljevića Sakcinskog, Ivanec & 5 & 10 & 2 & 17 \\
\hline ES Braće Radića, Botinec, Zagreb & 5 & 34 & 0 & 39 \\
\hline ES Braće Bobetko, Sisak & 4 & 17 & 5 & 26 \\
\hline ES Darda, Darda & 3 & 19 & 0 & 22 \\
\hline ES prof. Franje Viktora Šignjara, Virje & 5 & 34 & 5 & 44 \\
\hline ES Ljudevita Modeca, Križevci & 7 & 30 & 0 & 37 \\
\hline ES Dobriše Cesarića, Zagreb & 3 & 10 & 0 & 13 \\
\hline ES Trilj, Trilj & 3 & 18 & 2 & 23 \\
\hline ES Čazma, Čazma & 5 & 24 & 1 & 30 \\
\hline ES Nikole Andrića, Vukovar & 3 & 10 & 0 & 13 \\
\hline ES Vežica, Rijeka & 3 & 18 & 0 & 21 \\
\hline ES Ivana Rangera, Kamenica & 3 & 11 & 2 & 16 \\
\hline ES Marina Getaldića, Dubrovnik & 5 & 26 & 0 & 31 \\
\hline ES oca Petra Perice, Makarska & 0 & 0 & 0 & 0 \\
\hline Traffic school Rijeka & 2 & 12 & 0 & 14 \\
\hline Gymnasium of Ivan Zakmardy Dijankovečki, & 4 & 23 & 1 & 28 \\
\hline Križevci, & & & & \\
\hline High school Marko Marulic, Slatina & 3 & 16 & 0 & 19 \\
\hline Catering school, Osijek, & 3 & 15 & 0 & 18 \\
\hline School for construction, natural history and \\
mining, Varaždin & 5 & 8 & 0 & 13 \\
\hline Woodcraft and carpenter school, Karlovac, & 5 & 17 & 0 & 22 \\
\hline Tehnical school Čakovec & 8 & 16 & 2 & 26 \\
\hline Industrial - craft school, Sisak, & 0 & 0 & 0 & 0 \\
\hline Total & $\mathbf{8 4}$ & $\mathbf{3 6 8}$ & $\mathbf{2 0}$ & $\mathbf{4 7 2}$ \\
\hline & & & & \\
\hline
\end{tabular}

Activities conducted during the Night reading sessions beside the ceremonial reading

The basic goal of popularization of the enjoyment reading was supported by the numerous activities which had the function of attracting the pupils - users of the school library to participate in this action. The activities had to be fun, but they also were based upon the non-formal educational principle. Their number and variety is impressive: games of association, „Calodont" game, „Guess who am I?" game, „Guess the song“ game, mime, Boggle, Memory, Pictionary, twitter, interactive computer games „Priče iz davnine“, „Pričam ti priču“, „Pogodi osobu“, movies (Avatar, Polar express, Dead Poet Society, Paranormal, Harry Potter - Deathly hallows, Casper, Kung Fu Panda 2, Happily NEver After, karaoke, „skyping“ with the pupils of other libraries, picnic with blankets, creation of personal bookmarks, literary meetings with Sunčica Orešić, Niveska Juraga-Kovačev, Nada Lapić, poem writting workshop, „film matinee“ of the Media group ES Virje, Movie club Karlovac, dancing, introduction of the project Reading to the Stars, singing competition, ,singing fruit salad“, „movie marathon“, fairy tales telling with the guessing game, musical concert of the pupils, fairy tale reading to the little guests, creation of the common story, art-literary workshops, Songs 
from the Hat, Symbolics of words, Comic about the Ow(1)etter party, making of the advent garland, painting of the library wall, recording of the millionth greeting for Nova $\mathrm{Tv}$, visit to the promotion of the book in the Town library and the concert in the Music school, charity event, masquerade „My character and I“", scene play Several lonelinesses.

The gathered evaluation papers point to the fact that the participants were very enthusiastic and satisfied with the Night reading session, which remained the topic No 1 of the talks in the schools.

\section{Readings conducted in the local community}

After the Night reading session, the next phase of the Ow(1)etter party project was initiated, Reading in the local community. Until the time of writing of this article, the following libraries visited the external institutions:

- ES Braće Bobetko, Sisak, Home for the Elderly; March 15th, socializing with the mountaneers of the HPD „Zrin“ on Hrastovička gora; May 8th the excursion We read in the heart of glagollic alphabet - Roč, Hum and Motovun;

- Industrial - craft school, Sisak, March 15th socializing with the mountaneers of the HPD ,Zrin“ on Hrastovička gora; May 8th the excursion We read in the heart of glagollic alphabet - Roč, Hum and Motovun;

- ES Braće Radića, Botinec, Zagreb, November 16th, December 21st, February 21st and April 6th, Home for the Elderly „Rezidencija Kaštelan“; April 26th 2012 presentation of the Ow(1)etter party project on the County committee for the democratic citizenship, and on May 22nd 2012 presentation of the Ow(1)etter party project on the Gathering of the project from the area of National program of Human Rights and Democratic Citizenship Education, where it was included in the project „Tko pjeva, zlo ne misli“ („One Song A Day Takes Mischief Away")

- Catering school, Osijek, November 18th, reading to all pupils of the school through the public address

- ES Darda, Darda, December 20th the shop Konzum in Darda

- Woodcraft and carpenter school, Karlovac, March 30th, the recital which connected our project with the „Crocus“ project; also, pupils from the ES Dragojle Jarnević and School for economics and tourism, Karlovac, were present.

- Gymnasium of Ivan Zakmardy Dijankovečki, Križevci, March 21st Kindergarten „Ray of Sun“ April 23rd presented the Ow(l)etter party project within the scope of the event Night of the Book in the Town library „Franjo Markovićc" in Križevci

- ES Ivan Kukuljević Sakcinski, Ivanec, April 23rd - 28th Reading to the pupils of 2 nd grade in the home school and branches of the school on the World Book 
Day and the Day of Croatian Book, on May 6th and May 19th, reading for the visitors in the museum Trakošćan Castle, May 2nd - 4th.

- ES Marin Getaldić, Dubrovnik, May 7th reading to the pupils from 1st to 3rd grade;

- School for construction, natural history and mining, Varaždin; May 22nd, the protegees of the association „Ludbreg Sun“ (children with special needs)

Until now, there were 10 active school libraries in the second phase, which is a satisfying result. This phase of the project is more demanding, because there are no prepared ideas and materials; the implementation is based upon the creativity of teams and students in search for institution which will be visited in the local community, and upon the good will of the local community. We can testify to it on our own example from 5 submitted requests for reading, we got only 2 positive answers. One of the possible reasons for such results is the non-defined Time schedule of activities, in which it was not stated that every team member (including the pupils) is obliged to ensure one institution for reading, which we plan to change if we continue with a new cycle this year. From the institutions where the reading was implemented, we got very positive reactions both by the auditory and by our teams, so that every now and then a team posts an enthusiastic status related to the reading on the Facebook group Tulum s(1)ova.

\section{Media exposure of the Ow(l)etter party project}

The project has generated a large media interest. We gathered 63 media publications, announcements (23) or reports (40). The links and other publications were gathered non-systematically, so we suppose that the list is longer. We have learned that we needed to make one member of the team responsible for gathering of the publications from the bery beginning. This will be improved in the new cycle, so the list of the publications is more accurate. However, this list is a result of our recognition of the importance of the media as the means of promotion of the work oh our profession, which will help us to achieve better perception of our profession in the educational system and in the general public. The team for project implementation from ES Ivana Kukuljevića Sakcinskog, Ivanec had a task to contact the official media, while the school teams informed the local media. All media have published positive reviews of our project.

\section{The time ahead}

Very soon, the academic year is over, and the pupils will go to the deserved holidays. During the holidays we did not plan any reading in the local community; this does not mean they will not take place, if the teams will have enough enthusiasm to do that. When they return to the schools, they have another month for reading implementation. After this, the evaluation phase is due. Until the end of the third phase of the project, the team for project implementation has the task to construct the Evaluation paper for the whole project, while the Regulatory book about the selection of the most successful school library, the criteria for selection and awarding will be written and adopted on the suggestion of the author of the project, and the chairpersons of the Croatian Network of School Librarians and the Croatian Association of School Librarians on the Sessions of the Administrative Boards of both associations. At the moment, the ceremonial 
award to the most successful library is planned, as well as the simbolic awards for all included libraries. The awards will be given with the media presence at the state level, in Zagreb.

\section{Conclusion}

The Ow(l)etter party project has as a basic goal the strenghtening of the positive attitude of the pupils toward the enjoyment reading. It was therefore designed in such manner to meet the needs of the pupils. By participating in the project, the pupils have fun, the opportunity to present to the others what they think is valuable (their enthusiasm for the enjoyment reading), implementing the noble project with their friends and school personnel, and in such way they develop the sense of togetherness and belonging. In such way, the enjoyment reading acquires an permanent value, which will follow them through the whole life. They will be able to share this with all people who will be the part of their lives. The reactions of the children and the team member, media and local community representatives are for us an encouragement to continue with the project in the next year. Our experience has shown how to improve the project, and we have a desire to extend it across our borders.

\section{References}

IFLA-in i UNESCO-ov Manifest za školske knjižnice (2004). In Saetre, T. P. \& Willars, G. (Eds.) IFLA-ine i UNESCO-ve smjernice za školske knjižnice (pp 31-34). Zagreb: HKD.

Ministarstvo znanosti, obrazovanja i športa. (2011). Nacionalni okvirni kurikulum za predškolski odgoj $i$ obrazovanje te opće obvezno $i$ srednjoškolsko obrazovanje (MZOŠ)

Author Note

Drazenka Stancic has graduated croatian language and literature and librarianship. She is employed as a school librarian working at the Elementary school Ivana Kukuljevica Sakcinskog, Ivanec. She is an active participant of the Croatian school library community. From the year 2009 she is a member of Governing Board Croatian Network of School Librarians (CNSL). In the Croatian Association of School Librarians (CASL) she holds a position of secretary for the period of 2009-2012. She has presented several papers on annual Spring School of School Librarians. Her area of expertise are school libraries, reading and media education. 